\title{
Potential of bryophytes in nanotechnolohy: An overview
}

\author{
Afroz Alam*, Prachi Baliyan*, Vinay Sharma** and Mazhar-ul-Islam*** \\ *Department of Bioscience and Biotechnology, Banasthali Vidyapith, Banasthali-304022, Rajasthan, India \\ **Amity Institute of Biotechnology, Amity University, Jaipur-303002, Rajasthan, India \\ ***Cryptogamic Laboratory, Department of Botany, Hazara University, Mansehra-21300, Pakistan
}

\section{Article Info}

Article history

Received 7 January 2021

Revised 8 February 2021

Accepted 9 February 2021

Published online 30 March 2021

Keywords

Antioxidant

Bryophytes

Medicinal properties

Nanoparticles

Water relations

\begin{abstract}
Bryophytes, the amphibian of plant kingdom constitute the second largest group of land plants after angiosperms have remarkable reputation as the ecologically important group of plants. But, the other properties of these plants such as medicinal or therapeutic uses are usually neglected by the researchers and they are remained unexplored in past on these important aspects. However, with increasing knowledge and techniques, these plants are now emerging as a precious pool of important properties. On medicinal aspects of these plants, some articles have been published in recent past but on green synthesis related upholding of these plants, there is insufficient information available till date. This review is an attempt to fill a gap and provide an insight view on the potential of bryophytes as preferred system for nanoparticles synthesis or green synthesis.
\end{abstract}

\section{Introduction}

Bryophytes constitute the second largest group of land plants after phenerogams. They are the first land plants and also known as Lilliputians of plant kingdom because of their miniature size. Although, these plants are immensely distributed worldwide under three classes, viz., liverworts, hornworts and mosses, yet the information related to their medicinal importance is very limited as their size.

According to few reports, bryophytes are popular remedy among the various tribes of the world and they prefer to use these miniature plants to cure several diseases in their day-to-day lives. Tribal peoples used these plants to cure skin diseases, hepatic disorders, cardiovascular diseases, inflammations, microbial infection, wound, etc. Recent attempts on bryophytes showed that these plants have significant antitumor activities counter to diverse sarcomas' cell lines and this possession of bryophytes is getting special attention by many workers nowadays.

Likewise, nanotechnology is now a most encouraged and highly captivated science among the modern researchers. Nanotechnology grips numerous fields including life science arena related to biomedical field to drug delivery (Patra et al., 2018). There are several methods employed to develop the synthesis of nanoparticles including biological method (Pandit and Zeugolis, 2016). Since, biological methods are greener and no risky chemicals are involved compare to other available methods. Therefore, the green synthesis is preferred approach over the physical and chemical methods (Singh et al., 2018).

\section{Corresponding author: Dr. Afroz Alam}

Associate Professor, Department of Bioscience and Biotechnology, Banasthali Vidyapith, Vanasthali-304022, Rajasthan, India

E-mail: afrozalamsafvi@gmail.com

Tel.: +91-9415596994

Copyright $(\mathcal{C} 2021$ Ukaaz Publications. All rights reserved.

Email: ukaaz@yahoo.com; Website: www.ukaazpublications.com
The silver metal nanoparticle synthesis is more used method for green synthesis in comparison to other metals, viz., platinum, gold, copper and zinc (Dubey et al., 2010). It is happening due to its applicability in biomedical field as an antimicrobial and anticancer agent (Kalpana and Rajeswari, 2018). Earlier, the tracheophytes, viz., pteridophytes, gymnosperms and mainly the angiosperms were invariably used in the biosynthesis of silver nanoparticles and atracheophytes (bryophytes) were somewhat untouched or neglected. As a result, sporadic attempts were made using these miniature plants to synthesize the nanoparticles. However, all the three classes of bryophytes were explored for this purpose for instance Riccia (a liverwort), Anthoceros (a hornwort) and Fissidens (a moss) were effectively evaluated to generate the nanoparticles (Kulkarni et al., 2012).

The reason behind this is the special plant body which bryophytes have, i.e., very primitive and simple, gametophytic in nature, without any well-defined vascular supply for water and nutrient uptake. Further, they are the resurrection plants and absorb water directly from their thallus surfaces.

\section{Water relations}

The bryophytes do not have cuticle on leaves (ectohydric bryophytes) and stem surface (except seta) that is why absorption and transpiration of water can occur easily. They have high water holding capacity, for example, Sphagnum. While endohydric bryophytes have internal conduction system through central strand by symplastic mechanism. Due to these factors, they occur enormously in high humidity and low evaporation rate region.

The regulation of water flow is maintained by faster absorption and low transpiration. They can contribute to relative humidity in environment through evaporation. Bryophytes can quickly absorb moisture from dew, fog and mist. These are the sources of water which are rarely used by other plants (Glime, 2017). 
All these characteristics of bryophytes make them suitable plants to develop nanoparticles in the procedure of green synthesis. Consequently, after few attempts, some progress has been evident in this direction. In coming future, bryophytes would become the preferred choice for nanoparticles synthesis or green synthesis.

\section{Role of plants in nanotechnology}

The incorporation of nanotechnology in remedy has had an incredible influence in the recent past. The finding nanomaterials (NMs) synthesis and their purposes as multipurpose tools encouraged use of plants in nanomedicine and nanobiotechnology. Usage of plant extracts in the biological synthesis system bids unambiguous compensations over peptide, protein, enzyme, and DNA. Usually, various plant extracts have been utilized for medicine, food, NM synthesis, and bioprospecting (Taylor et al., 2014; Pérez-de-Luque, 2017). Numerous feasible methods have been developed for the availability of plant extracts with several contents based on their simple forms, economical nature, and the kind of extract. Hence, many plant species have been used in past for their extracts to be utilized in the synthesis of nanoparticles.

\section{Distinctiveness of bryophytes for nanobiotechnology}

Bryophytes are the pioneer of ecological succession along with lichens, hence they are well adapted to cope up with severe and naked environment which compelled them to develop several distinct mechanisms unlike other plants. Due to this remarkable adaptive nature, they showed great diversification and it is estimated that this group has about 18,000 and 23,000 extant species (Villareal et al., 2010).

Bryophytes have numerous traits of biological and ecological significance. They do not have lignin which prevents them to grow in to gigantic forms because of the deficiency of mechanical support. Hence, they remained miniature sized, i.e., up to few decimeters in stature. Since well protective cuticles are absent, therefore, they have specific type of water balance according to their ambient environment, i.e., they are poikilohydric in nature. Thus, many of bryophytes have the power of resurrection and able to resume metabolism with almost no injury to the thallus after a period acute growth restriction (Alam et al., 2019). Due to the absence of cuticle and roots, the whole plant body is able to obtain the water from the surroundings, and act as good indicator of alterations going on in their intimate environs. Hence, bryophytes have a colossalimpending to be used in the development of nanoparticles.

\section{Impending of bryophytes in nanotechnology}

Chemical ingredients of bryophytes fascinate the researchers recently and got attention. These plants have the reputation as a source of antimicrobial compounds. The bioactivities of extracts from many species were found promising to produce biopharmaceutical, biopesticides, or other cures. Due to the environmentally friendly attributes of these products, new technological processes with bryophytes are desirable to be recognized their concrete impending. They have great potential to be used in the treatment of diseases like AIDS, cancers and can also be utilized in the production of new antibiotics. Since they are very well known for skin treatment, therefore, cosmetic industry can also use these plants. The union of nanobiotechnology and bryology can do wonders in coming future.

\section{Possible bryophytes in nanotechnology}

As mentioned, many bryophytes have been evaluated for their biologically active compounds which have antiviral, antimicrobial and antioxidant properties (Singh et al., 2000).

Many moss taxa have shown great potential in having biologically active compounds and have great future in the formulation of nanoparticles, some of them are:Atrichum angustatum (Brid.) B.S.G. (antibacterial), Atrichum undulatum (Hedw.) P. Beauv. (antifungal), Anomodon rostratus (Hedw.) Schimp. (antimicrobial), Bryum cuspidatus Hedw. (wound healing), Barbula Hedw. (antibacterial), Camptothecium (Hedw.) B.S.G. (effective against polio virus), Dicranium Hedw. (antibacterial), Fissidens Hedw. (diuretic), Hyophila involuta (Hook.) Jaeg. (antibiotic), Haplocladium microphyllum (Hedw.) Broth. (antiviral), Polytrichum commune Hedw. (diuretic), Polytrichum juniperinium Willd. ex Hedw. (anticancer), Philonotis fontana (Hedw.) Brid. (antipyretic and antiinflammatory), Rhodobryum giganteum (Schwaegr.) Pars. (cardiac problems), Sphagnum L. (antimicrobial, antibiotic) (Singh et al., 2000).

Similarly, many liverworts have also shown bioactivity and in future they can be used in nanotechnology, viz., Chiloscyphus polyanthus (L.) Corda (anticancer), Dumortiera hirsuta Reinw. BL. et. Nees (antibacterial), Conocephalum conicum (L.) Mecker (to cure skin infections), Diplophyllum taxifolium (Wahl.) Dumort. (antitumor), Frullania tamarisci (L.) Dumort. (antileukemic), Marchantia polymorpha (to cure hepatic disorders), Marchantia palmata Nees (to cure liver problems), Pallavicinia S.F. Gray (antibacterial), Porella platyphylla (L.) Dum. (antibacterial), Radula campanulata (L.) Dum. (antimicrobial), Wiesnerella denudata (Mitt.) Steph. (kidney problems) (Singh et al., 2000).

\section{Recent progress with bryophytes in nanotechnology}

Keeping the distinctiveness of bryophytes, some attempts have been made in recent past in this direction. Recently a moss, namely; Campylopus flexuosus (Hedw.) Bird. mediated synthesis and characterization of silver nanoparticles were done by Vimala $e t$ al. (2017). This obtained results are encouraging for the future attempts on the huge bryodiversity available worldwide. Beside, this the antioxidant potential of bryophytes is also remarkable along with the antimicrobial and anticancer properties, which makes these plants as a worthy system to work with nanoparticles.

\section{The drawbacks}

The major problem with the bryophytes to work with is the insignificant availability of biomass, their extreme habitats and they are tough to identify. Therefore, they are somewhat neglected in other aspects except their ecological role.

\section{Remedial approach}

However, the establishment of axenic and in vitro growth chambers for few certain species can overcome these difficulties and a workable biomass can be obtained. However, this set-up will require a coordination amid classical bryologists, biotechnologists and nanobiotechnologist to get desirable success with small plants for synthesis of nanoparticles. Who knows the future of nanobiotechnology shall belongs to these neglected plants of present time? 


\section{Conclusion}

Due to their uniqueness, the huge bryofloristic wealth is available for mankind and there is need to explore these tiny plants in the light of newly developed technologies. Currently, many angiosperms and gymnosperms are being used in the nanotechnology, but these minute plants are usually neglected just because of few basic points, viz., hard to collect and identify. However, huge amount of work has been done on the identification and classification of these plants and this aspect is data rich at present. If, the identified taxa can be grown through tissue culture in desire amount, then it is certain that few of the bryophytes will do miracle and can be more efficiently used in the cure of several diseases in future. The evidenced antimicrobial potential will offer a tool to develop a powerful antimicrobial formulation through green synthesis of nanoparticles.

\section{Conflict of interest}

The author declares that there are no conflicts of interest relevant to this article.

\section{Acknowledgements}

The authors are grateful to Professor Aditya Shastri, Vice-Chancellor, Banasthali Vidyapith for his encouragement and support.

\section{References}

Alam, A., Dwivedi, A. and Emmanuel, I. (2019). Resurrection plants: Imperative resources in developing strategies to drought and desiccation pressure. Plant Sci. Today, 6(3):333-341. https:// horizonepublishing.com/journals/index.php/PST/article/view/542

Dubey, S.P., Lahtinen, M. and Sillanpää, M. (2010). Tansy fruit mediated greener synthesis of silver and gold nanoparticles. Process Biochem., 45:1065-1071. https://doi.org/10.1016/j.procbio.2010. 03.024 .

Glime, J.M. (2017). Light: Adaptations for shade. Chapt. 9-2. In: Glime JM. Bryophyte Ecology. Volume 1. 9-2-1 Physiological Ecology. E-Book sponsored by Michigan Technological University and the International Association of Bryologists. Last updated 17 July 2020.<http://digitalcommons.mtu.edu/bryophyte-ecology/>.
Kalpana, V.N. and Rajeswari, V.D. (2018). A review on green synthesis, biomedical applications, and toxicity studies of $\mathrm{ZnO}$ NPs. bioinorganic chemistry and applicationsVolume 2018, Article ID 3569758 , pp: 12 .

Kulkarni, A.P., Srivastava, A.A., Nagalgaon, R.K. and Zunjarrao, R.S. (2012). Phytofabrication of silver nanoparticles from a novel plant source and its application. International Journal of Biological and Pharmaceutical Research, 3:417-421.

Pandit, A. and Zeugolis, D.I. (2016). Twenty-five years of nanobiomaterials: Have we revolutionized healthcare? Fut. Med., 11(9):985-997.

Patra, J.K., Das, G. and Fraceto, L.F. (2018). Nano based drug delivery systems: Recent developments and future prospects. J. nanobiotechnol., 16:7.https://doi.org/10.1186/s12951-018-0392-8

Pérez-de-Luque, A. (2017) Interaction of nanomaterials with plants: What do we need for real applications in agriculture? Front. Environ. Sci., 5:12. https://doi.org/10.3389/fenvs.2017.00012

Sabovljević, M.S. and Sabovljević, A.D. (2020). Bryophytes. Intech open. https://doi.org/10.5772/intechopen.91420

Singh, A.P., Asthana, A. and Nath, V. (2000). Medicinal importance of bryophytes: A description Council of Scientific and Industrial Research Booklet. Issue, 2:55-62.

Singh, J., Dutta, T. and Kim, KH. (2018). 'Green' synthesis of metals and their oxide nanoparticles: applications for environmental remediation. J. Nanobiotechnol, 16:84. https://doi.org/10.1186/ s12951-018-0408-4

Taylor, A.F., Rylott, E.L. and Anderson, C.W.(2014). Investigating the toxicity, uptake, nanoparticle formation and genetic response of plants to gold. PLoS ONE, 9:e93793. https://doi.org/10.1371/journal.pone. 0093793

Villareal, J.C, Cargill, D.C. and Hagborg, A. (2010). A synthesisof hornwort diversity: Patterns, causes and future work. Phytotaxa., 9:150-166.

Vimala, A. Sathish, S.Sahaya. and Thamizharasi, T. (2017). Moss (Bryophyte) mediated synthesis and characterization of silver nanoparticles from campylopus flexuosus (Hedw.) Bird. J. Pharm. Sci. and Res., 9(3):292-297. 